\title{
Oocyte structure and ultrastructure in the Mexican silverside fish Chirostoma humboldtianum (Atheriniformes: Atherinopsidae)
}

\author{
Rodolfo Cárdenas ${ }^{1}$, Mónica Chávez¹, José Luis González¹, Patricia Aley², Jesús Espinosa² \& \\ Luis Felipe Jiménez-García ${ }^{3}$ \\ 1. Laboratorio de Endocrinología de Peces, Unidad de Morfología y Función, F.E.S.-Iztacala, U.N.A.M.; rodolf@servi- \\ dor.unam.mx \\ 2. Laboratorio de Neuromorfología, U.I.I.C.S.E., F.E.S.-Iztacala, U.N.A.M. \\ 3. Laboratorio de Microscopia Confocal, Facultad de Ciencias, U.N.A.M.
}

Received 11-VII-2007. Corrected 30-VI-2008. Accepted 31-VII-2008.

\begin{abstract}
Mexican fish have received scarce attention. This study describes the histological and ultrastructural characteristics of the oocyte in Chirostoma humboldtianum. The ovary is asynchronic, and as such, most phases of oocyte development are found in the same ovary. The complete process of oogenesis was divided in five stages: oogonium and folliculogenesis, primary growth, cortical alveoli and lipid inclusions, vitellogenesis and maturation. The presence of big filaments, which appear at the end of primary growth, induces some common follicular adaptation. During primary growth, abundant ribosomes, rough endoplasmic reticulum, and mitochondria are grouped in the cytoplasm. At the end of this stage, the Z1 layer of the chorion is developed, while microvilli start to be evident as well. In the cortical alveoli and lipid droplets phase, intense PAS positive vesicles, some of them containing nucleoid material, are observed in the peripheral cytoplasm and the lipid droplets take a more central position. In vitellogenesis, the proteic yolk accumulates in a centripetal way while the chorion is completely formed. In maturation, the germinal vesicle migrates to the animal pole, meiosis is restored, and there is nuclear breakdown. The oocyte increases its size and holds some oil droplets and a big fluid mass of yolk. On the outside, filaments surround the oocyte completely. Rev. Biol. Trop. 56 (4): 1825-1835. Epub 2008 December 12.
\end{abstract}

Key words: Chirostoma, ovary, ultrastructure, oocyte, teleost.

Oogenesis is a fundamental phase in the reproductive process of organisms. Its comprehension is essential to understand the reproductive biology of species. Moreover, it provides a detailed picture of the reproductive state of females, which permits us to design and improve management proposals for species of economic importance. Histological studies on oogenesis provide some information, but they present several limitations when applied to vertebrates.

Teleosts are the biggest group of vertebrates. Hence, there is much diversity found in their oogenesis processes. Chirostoma humboldtianum (Mexican silverside fish) is an endemic freshwater fish from central and western Mexico. This genus includes several small species, locally named 'charal', and bigger species, called Mexican silverside fish, which have been used for human consumption since Prehispanic times and, hence, are of economical importance.

Previous investigations about this genus have dealt with its taxonomy (Barbour 1973a, Dyer and Chernoff 1996), geographical distribution (Barbour 1973b), morphological studies (Barriga-Sosa et al., 2002), and histological and ultrastructure of spermatogenesis (Cardenas and Barrera 1998). 
The aim of this work is to describe the structure and ultrastructure of the ovary, especially of oocytes of Ch. humboldtianum.

\section{MATERIALS AND METHODS}

Collecting site: Mexican silverside fish specimens were collected from the Zacapu lagoon in the State of Michoacan, Mexico, located between $19^{\circ} 40^{\prime} 40^{\prime \prime}$ and 19 $9^{\circ} 49^{\prime} 26^{\prime \prime} \mathrm{N}$, and $101^{\circ} 46^{\prime} 45^{\prime \prime}$ and $101^{\circ} 47^{\prime} 25^{\prime \prime} \mathrm{W}$.

Laboratory procedures: After collection, the fish were first anaesthetized with MS 222, and then measured and killed by transversal section. For light microscopy (LM), the ovaries were removed and fixed in $2 \%$ paraformaldehyde (in saturated picric acid and phosphate buffer solution, $\mathrm{pH}$ 7.4, or Bouin's solution) for $24 \mathrm{hr}$. The samples were dehydrated with alcohol and included in paraffin, cut at 1-5 $\mu \mathrm{m}$ and stained with hematoxylin and eosin or PAS. Finally, the sections were mounted with Entellan ${ }^{\circledR}$. Preparations were observed using a Leica ${ }^{\circledR}$ DM microscope and images were processed with a Leica ${ }^{\circledR}$ Qwin processor. For electron microscopy (TEM), other samples were fixed in $4 \%$ glutaraldehyde in cacodylate buffer ( $\mathrm{pH}$ 7.4) or glutaraldehyde and paraformaldehyde mix in phosphate buffer. These samples were postfixed with $1 \%$ osmium tetraoxide, dehydrated with alcohol, included in plastic resin (EPON), cut with an ultramicrotome and contrasted with uranyl acetate and lead citrate. Observations were done in a Jeol $100 \mathrm{X}$ or a Jeol 1200 EX transmission electron microscope.

\section{RESULTS}

Ovary: The ovaries of Ch. humboldtianum are paired and elongated organs, attached to the abdominal wall throughout the mesorchium. On the posterior part, the ovaries continue in a short gonoduct. Immature ovaries are whitecoloured with small black dots due to melanophore cells that, during development, start to proliferate and cover the whole surface, in consequence, the gonads become completely black. This pigmentation of the ovaries remains for the rest of the female's life (Fig.1A, 1B).

The ovary wall shows smooth muscles. In young females, only few muscle cells form part of this organ-binding wall, but in time, these cells proliferate, resulting in a more developed and thicker layer (Fig. 1A,1B).

Structure and ultrastructure of ovary: Ovaries are asynchronic and show different cell types during their development. Inside, lamellae are distinguished, specially during primary growth in young fish. The complete oogenesis process was divided in five stages: early oogenesis (formation of young oocytes from oogonia and folliculogenesis), primary oocyte growth, cortical and lipid stage, vitellogenesis, and maturation.

Early oocytes (size $\sim 10-25 \mu \mathrm{m}):$ In the ovaries of adults, oogonia are seldom identified because they lie close to the epithelial cells. In this study, oogonia proliferation was not observed. Oocytes in meiosis (Fig. 1C) or late stages are found in small groups, and they have a spherical nucleus with a single nucleolus, and a discrete amount of cytoplasm with ribosomes, mitochondria, and endoplasmic reticulum. The follicle cells start to enclose the oocyte during the initial meiosis process (Fig. 1D).

Primary oocyte growth (size $\sim$ 25-270 $\boldsymbol{\mu m})$ : The first phase of oocyte growth starts with the arrest of meiosis in diplotene. At this moment, the nucleus is spherical and in a central position. Initially, the nucleoli are scattered throughout the nucleoplasm, but soon they take a more peripheral location, close to the nuclear envelope (Fig. 1E). There is abundant material flowing from the nucleus to the cytoplasm. Under LM, the oocytes show a highly basophilic cytoplasm and only few structures, like the endoplasmic reticulum, can be distinguished. Basophylia is due to abundant free ribosomes that give the cytoplasm its granular appearance. Also, groups of mitochondria are 

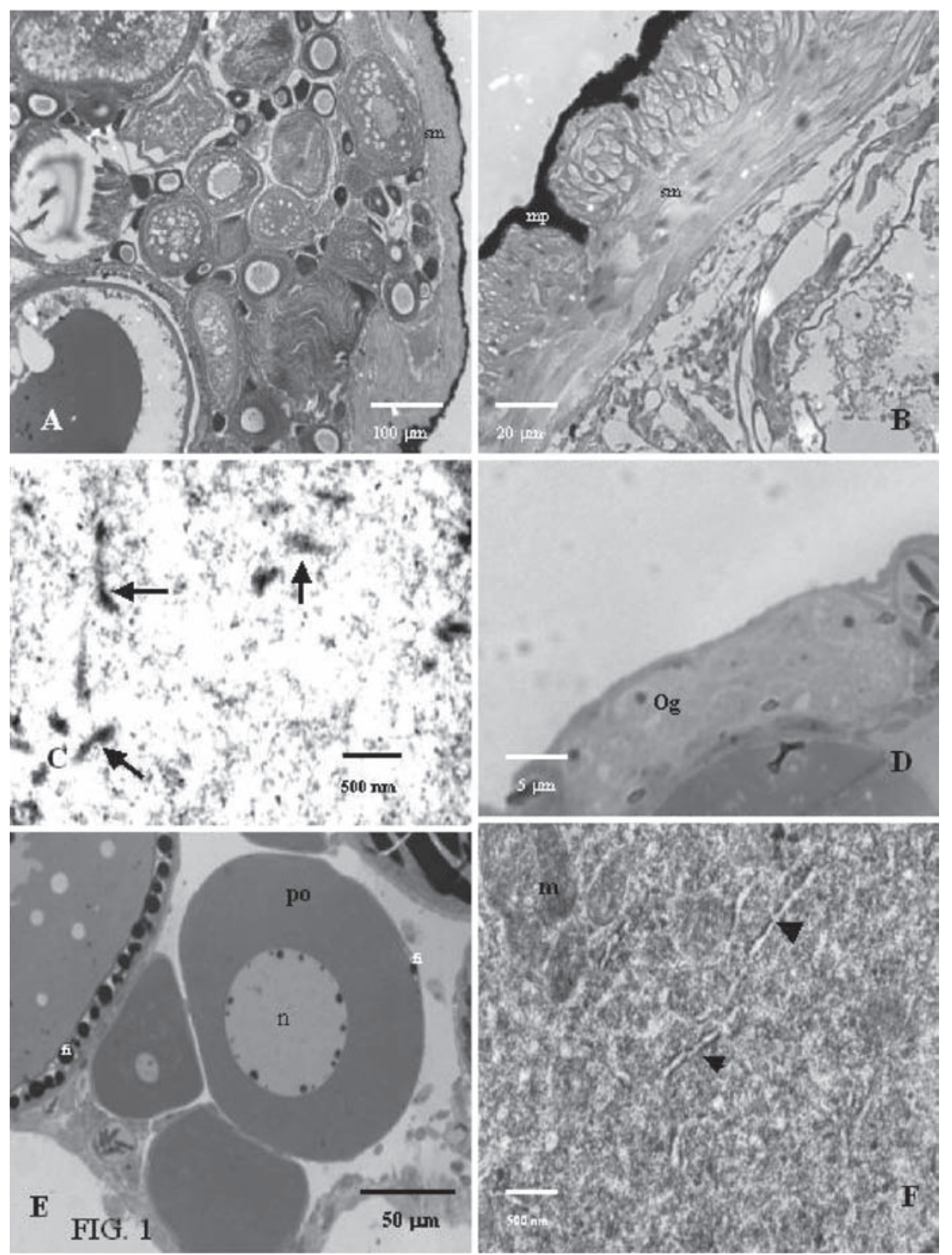

Fig. 1. The ovary of Chirostoma humboldtianum. A) Section of an ovary showing the wall and follicle at all development of stages, LM; B) Section of a detail of the wall, LM; C ) Early meiotic oocyte, TEM; D) Early oocytes, LM; E) Oocyte in primary growth, LM; F) Cytoplasm of oocytes during primary growth, TEM; mp, melanocytes; sm, smooth muscle; og, early oocytes; m, mitochondria; n, nucleus; arrows, synaptonemal complex; arrow heads, rough endoplasmic reticulum; po, primary growth oocyte. 
present. These organelles are rounded with numerous cristae (Fig 1F). As the development of the oocyte continues and its size increases, basophylia diminishes and more membrane organelles, like the rough endoplasmic reticulum (RER) and the Golgi complex, begin to be apparent. By this time, mitochondria are distributed throughout the cytoplasm, even in the peripheral region of the oocyte. In the last phases of this stage, the chorion (vitelline envelope or zona radiata) starts to be formed, especially layer one (Z1). Under LM, it is PAS positive, suggesting a carbohydrate nature, and under EM, it appears as an electrodense structure (Fig. 2A, 2B). Some oocyte microvilli can be found reaching the extracellular space close to the follicular (granulosa) cells, which are flat and surround the oocyte in one single layer (Fig. 2A, 2B). In the young follicle systems, granulosa cells contain few mitochondria and endoplasmic reticulum. At the end of this phase, however, their morphology changes as they grow thicker. Outside the chorion, filaments start to be distinguished. They are acidophilic when seen under LM (Fig. 1E, 2C), while, under EM, they look like electrodense material (Fig. 2F, 3A). During the rest of oogenesis, the filaments continue to grow and are rolled around the oocyte (Fig. 3B), increasing their diameter as the oocyte develops. Their function is to attach the developing embryo to the substrate.

Secondary oocyte growth. Lipid stage

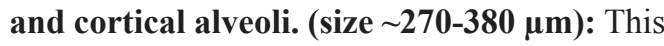
stage begins when cortical alveoli and lipid vesicles are formed, which are easily observed under LM (Fig. 2C). The lipid vesicles are homogeneous, moderately electrodense and have a smooth inner surface. Lipid accumulation continues also during vitellogenesis. We were not able to identify whether the lipids have an extragonadal or gonadal origin.

Cortical alveoli are located in the peripheral cortex. Two kinds of vesicles can be distinguished: one with homogeneous inner material and another with nucleoids. Under LM, both vesicles are PAS positive structures.
Nucleoids are seen individually or as fused particles. Under EM, the homogeneous cortical alveoli are observed with fine granular materials inside and nucleoid alveoli have different degrees of electrodense materials inside (Fig. 2C, 2D). Also, the cytoplasm contains sparsely distributed free ribosomes, rough endoplasmic reticulum, and mitochondria (Fig. 2E), visible as weak basophilic cytoplasm. Inside the nucleus, the chromatin is fine granular and nucleolar material still lies on the envelope.

The oocyte microvilli are still extending throughout the chorion towards the granulosa cells (Fig. 2F).

During this stage, the granulosa cells change their morphology completely. In order to approach the oocyte, these cells form a prolongation that passes between the filaments towards the oocyte vicinity (Fig. 2F). The follicle cells have vacuoles in their cytoplasm that are observed both under LM and EM (Fig. 3A). Besides, in these cells, an important development of endoplasmic reticulum is observed. There is a basal lamina outside of the follicle cells and, on its external face, flat theca cells are located. Often, several blood vessels are associated with the follicle (Fig. 2F, 3A).

Vitellogenesis (size $\sim \mathbf{3 8 0 - 6 5 0} \mu \mathrm{m})$ : This stage is characterized by a substantial increase in oocyte size, caused by the incorporation of external materials inside the ooplasm. The oocyte accumulates membrane bound yolk platelets that increase their size according to oocyte development (Fig. 3C). The chorion is becoming thicker as more extra-gonadal proteic layers are added (Z2 and Z3), with the most internal layer having a geometrical arrangement (Fig. 3D, 3E). The microvilli cross through chorion pores (Fig. 3D, 3F), and are always localized just in front of the granulosa cells. These cells increase their size becoming columnar and present clusters of round mitochondria and abundant rough endoplasmic reticulum (Fig. 4A). In addition, some vacuoles are seen inside the cytoplasm, and the abundance of these structures suggests elevated steroids synthesis (Fig. 3F, 4A). Due to the 

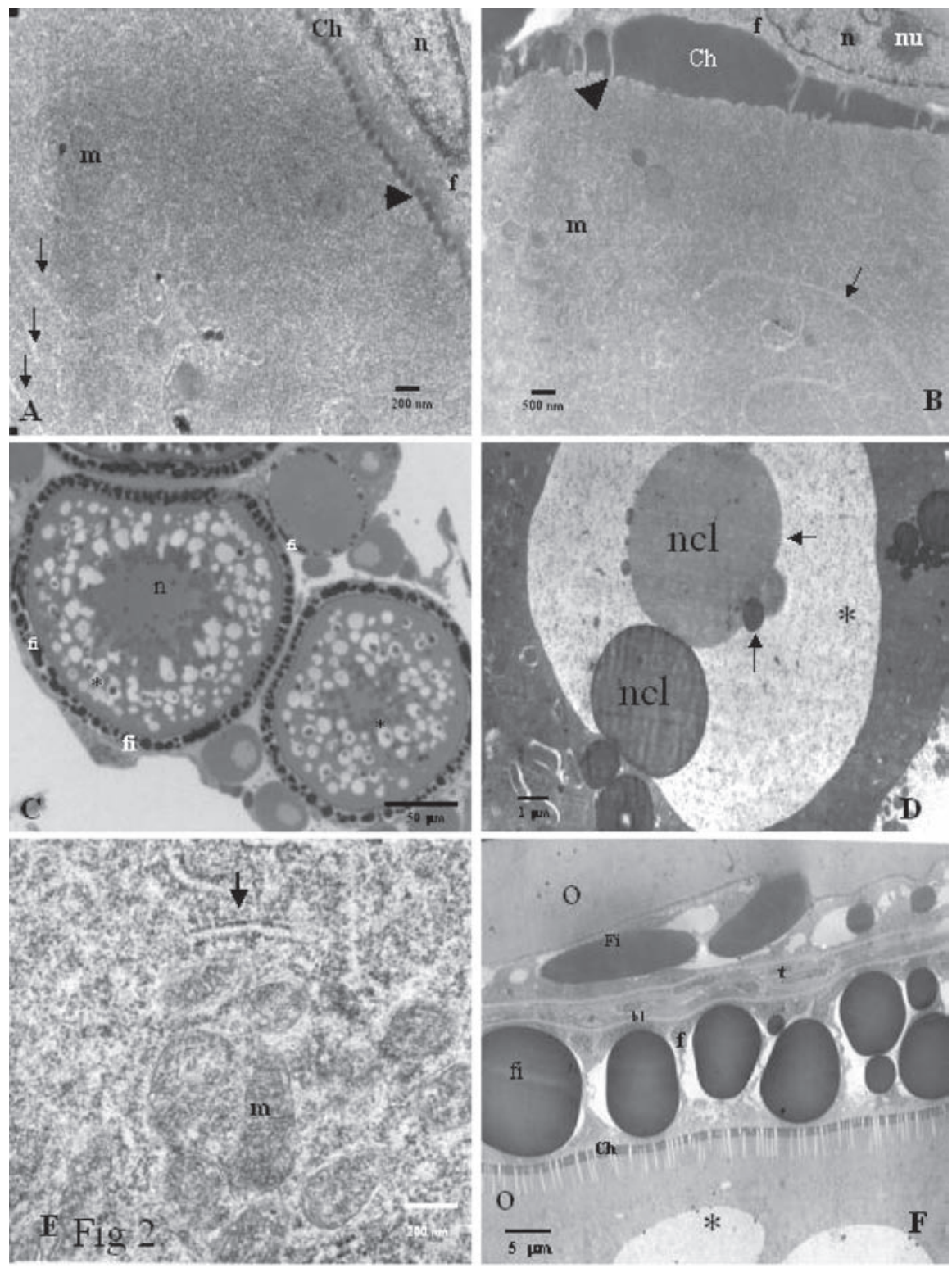

Fig. 2. Primary growth oocytes TEM. A - B) m, mitochondria; Ch, chorion; f, follicle cell; n nucleus; nu, nucleolus ; arrows, endoplasmic reticulum; arrow head, microvilli; fi, filaments. TEM. Cortical alveoli oocytes. C) LM. E - F) TEM. asterisk, cortical alveoli; n; nucleus; fi, filaments; m, mitochondria; ncl, nucleoid; arrow, endoplasmic reticulum, Ch chorion; O, oocyte; f, granulosa cells; bl, basal lamina; t, theca cells. For more details, see text. 

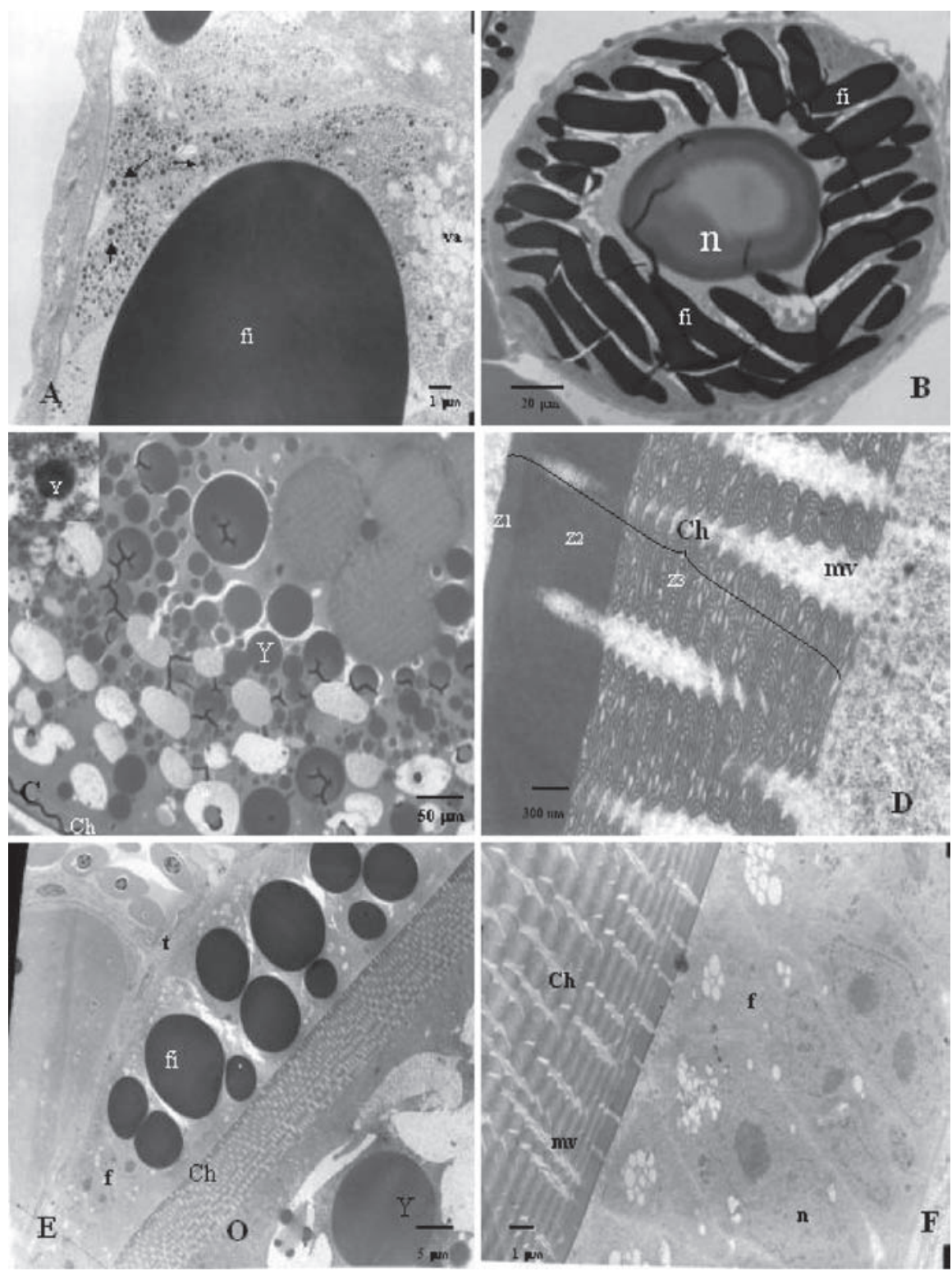

Fig. 3. Cortical alveoli oocytes. A) TEM. B) LM: fi, filaments; n, nucleous; va, vacuoles; arrows, dark inclusions into the granulosa cells; Vitellogenic oocytes C) TEM: Inset in top right angle coated clathrin vesicle; D-F) TEM: Ch, chorion; mv, microvilli; Z1, Z2, Z3, layer 1, 2 and 3 of the chorion respectively; O, oocytes; fi, filaments; Y, proteic yolk; t, thecal cell; f, granulosa cells; asterisk, cortical alveoli; n, nucleous. 


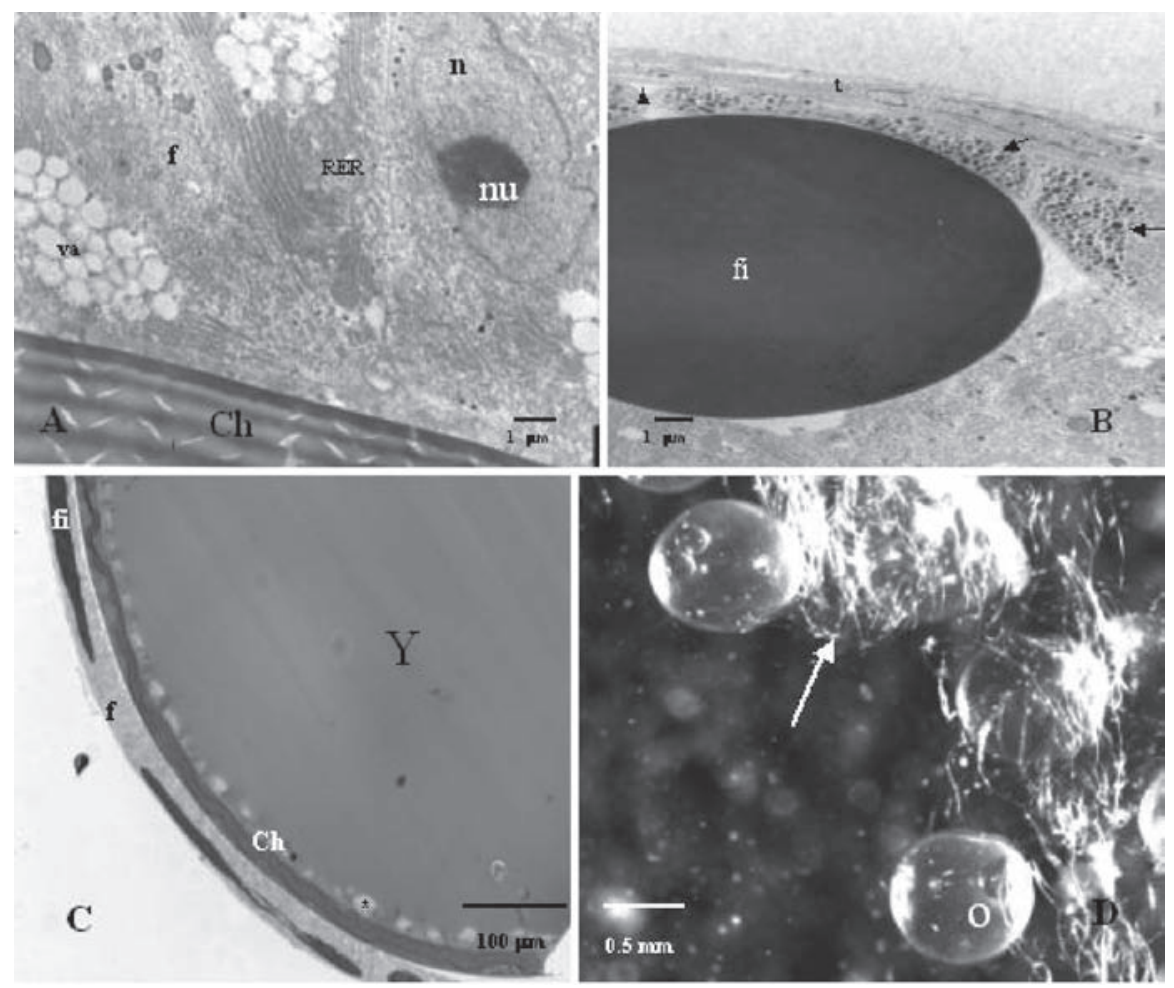

Fig. 4. Granulosa cells. A-B) TEM: Ch, Chorion; va, vacuole; RER, rough endoplasmic reticulum; n, nucleous; nu, nucleolus; f, granulosa cell; fi, filaments t, theca cells,; arrows, dark inclusions in granulosa cells. Matture oocytes. C-D) LM: Y, yolk; O, oocyte; fi, filaments; Ch, chorion; asterisk, cortical alveoli; arrow, entire filaments.

increase of the filaments' diameter sometimes they seem to be pseudostratified (Fig. 3F). It would be interesting to investigate whether the interaction with the oocyte brings about a differential function of the closer granulosa cells. Some dark inclusions are also found inside the cells, close to the basal lamina, indicating an active flow of substances (Fig. 3A, 4B). Probably, these inclusions are precursor materials that will be incorporated in the filaments. In this stage, some desmosomes are even present among granulosa cells. Theca cells do not change their morphology during oogenesis and they remain as flat cells outside the basal lamina. The latter is thick and fibrous and displays collagen fibres oriented in parallel with the follicular surface (Fig. 2F, 4B).

Inside the ooplasm, there are small vesicles that enclose electrodense materials. High magnification shows that the vesicles are coated by clathrin (Fig. 3C). These clathrin-coated microspheres can be observed in the peripheral cytoplasm of the oocyte, indicating a selective transportation of material and suggesting an intense uptake of extracellular material. Once the spheres are internalized, they coalesce with others to form vitelline platelets. These platelets are stored centripetally. Some mitochondria, rough endoplasmic reticulum, and free ribosomes are still found in the periphery of the cytoplasm.

Maturation (size $\sim 650-1150 \mu \mathrm{m})$ : The oocyte continues to grow and the principal event of this stage is the resumption of meiosis. This begins with the nuclear migration to the animal pole of the oocyte. After this, the germinal vesicle breaks down. Protein yolk suffers 
disorganization, probably due to the hydrolysis of its components, resulting in an irregular mass occupying most of the central area of the oocyte (Fig. 4C). Lipids accumulated during vitellogenesis join together and form several distinguishable lipid (4-7) drops in the animal hemisphere (Fig.4D). All these events are followed by hydration of the oocyte.

\section{DISCUSSION}

General aspects: In this study, oocyte and follicle development in Chirostoma humboldtianum was divided in five phases based on histology and ultrastructural observations. These stages are compatible with other classifications commonly used in teleosts (de Vlaming 1983, Nagahama 1983, Selman and Walllace 1986, Wallace and Selman 1990, Selman et al., 1993, Tyler and Sumpter 1996). We used the term "lipid stage and cortical alveoli" in the same way as it was recently used by Abascal and Medina (2005).

Early oogenesis: The oogenesis in $C h$. humboldtianum is not very different from that in other teleosts (Selman and Wallace 1986, Wallace and Selman 1990, Grier 2000, CruzLandim and Cruz-Höfling 2001, Higashino et al., 2002, Abascal and Medina, 2005) and ultrastructural observations corroborate a similar development of the oocyte as in other species. It is generally accepted that oocytes in teleosts arise from the germinal epithelium that border the lumen of the ovary (Wallace and Selman 1990, Grier 2000). Just like in bluefin tuna, where mitotic proliferation of oogonia was not found (Abascal and Medina 2005), we could not find this phenomenon in adults of Mexican silverside fish, described for Centropomus undecimalis by Grier (2000). Early oocytes under meiotic conditions seem to be grouped in a similar way as in other teleosts (Selman et al., 1993, Grier 2000, Abascal and Medina 2005); their development seems synchronic and the presence of meiotic figures in the ovary epithelium of $C h$. humboldtianum confirms the importance of this layer (Selman and Wallace 1986, Wallace and Selman 1990).

Primary oocytes growth: During the primary growth of the oocyte, the nuage of different durations has been reported for several species, like Centropomus undecimalis and Thunus thynus (Grier 2000, Abascal and Medina 2005). For Ch. humboldtianum, the nuage seems more similar to that of $C$. undecimalis, where it happens at the initial folliculogenesis, in contrast to Thunus, where nuage is persistent until the lipid stage (Abascal and Medina, 2005).

As in many vertebrate species, primary growth is characterized by an active synthesis of RNAs, and, in this phase, this is easy to identify through the abundance of ribosomes and mitochondria in the cytoplasm. During this stage, it is common for the oocyte to have a nucleus with numerous peripheral nucleoli, as in most other teleost species (Selman and Wallace 1986, Cerdà et al., 1997, Blazer 2002, Patiño and Sullivan 2002, Patiño et al., 2003). Besides, like in Thunus thynus but contrary to Dicentrarchus labrax where chorion formation starts until the oocyte is in the secondary growth phase, the oocyte in Ch. humboldtianum develops the first chorion layer during primary growth, as observed under both LM and EM. It has been proposed that $\mathrm{Z} 1$ has a carbohydrate origin (Fausto et al., 2004), and its PAS positive structure confirms this in $C h$. humboldtianum. On the other hand, the other layers have a proteic nature (Begovac and Wallace 1989).

Secondary oocyte growth and vitellogenesis: The first evidence of nutrient accumulation is found during the secondary growth stage, when small lipid vesicles appear, which gradually increase in number and size. They start to fuse together, making larger inclusions that are arranged centripetally. This seems to be common in other teleosts too. It has been postulated that these inclusions are triacylglycerols rather than polar lipids (Mourente 
et al., 2002), and apparently oil droplets are functioning rather as a reserve substance than as structural lipids, which are available since the secondary growth phase. We could not determinate whether the origin of these lipids is extragonadal or gonadal.

Similarly to other fish, the ooplasm of $C h$. humboldtianum is very abundant in membranebound cortical alveoli, which derive from RER cisternae (deVlaming 1983, Selman et al., 1986, 1988). For Ch. humboldtianum, the frequency of these structures is high in the cytoplasm as compared with the bluefin tuna (Abascal and Medina, 2005) but similar to Fundulus (Selman and Wallace 1986) for both kind of vesicles with or without nucleoids but with fine granular materials inside. It has been discussed that the role of cortical alveoli is insignificant in the fertilization process $(\mathrm{deV}$ laming 1983; Selman et al., 1986, 1988, Tyler and Sumpter 1996, Abascal and Medina 2005), and for Mexican silverside fish, this seems to be another example of it, because the cortical alveoli lose significance as the oocyte develops. The cortical alveoli appear when the oocyte is around 180-200 $\mu \mathrm{m}$, just as in other teleosts (Selman and Wallace 1986, Patiño and Sullivan 2002, Abascal and Medina 2005).

In teleosts, the dramatic increase of oocyte size occurs together with proteic yolk intake during the secondary growth phase. This is possibly explained by the presence of numerous microvilli in the peripheral area of the oocyte, increasing the contact surface with the yolk and intake of material that is characterized by pits and vesicles. As has been established by Selman and Wallace (1983), vitellogenin circulates in the blood and displaces among the endothelial cells of the capillaries, and subsequently among follicle cells, reaching the region where microvilli are extending through the pores of the vitelline membrane (Selman and Wallace 1983, 1986, Smythe 2003).

In Chirostoma, there is a space between the borders of the microvilli and the granulosa cells that is filled with electrodense material, similar to what is found in the vesicles of the ooplasm. The same process has been described by Selman and Wallace $(1983,1986)$ and Abascal and Medina (2005).

These pits enter by endocytosis and form bigger vesicles and finally the yolk platelets, which are positioned more centrally. This process is fast and, for example, in Cyprinodon variegatus, the incorporation after intraperitoneal injection takes 20 minutes (Selman and Wallace 1983). In Ch. humboldtianum, we estimate that this process needs more time as the yolk has to cover a longer distance from the blood vessels to reach the microvilli.

Follicle cells have been reported to play a role in steroid production (Nagahama 1983, Nakamura and Nagahama 1993, Nagahama 1997). There is evidence that these hormones are accumulated in vacuoles inside the cytoplasm of granulosa cells in Chirostoma. The process seems to start during vitellogenesis and continues in maturation. The high activity of those cells is revealed through the abundant presence of endoplasmic reticulum from the moment the oocyte begins the secondary growth phase.

Mature oocyte: There are not many reports on filaments in the oocyte. As the $C h$. humboldtianum oocyte contains big filaments, it would be interesting to study follicles' physiology more thoroughly. In particular, it might be a good way of substance transport between the follicle cells and the oocyte.

\section{RESUMEN}

Los aspectos estructurales y ultraestructrurales de las gónadas de peces mexicanos endémicos han sido poco estudiados. En el presente trabajo reportamos las características histológicas y ultraestructurales del ovocito de Chirostoma hulmboldtianum. El ovario es de tipo asincrónico, por ende, la mayoría de las fases del desarrollo del ovocito pueden ser encontradas en el mismo ovario. El desarrollo del ovocito fue dividido en cinco etapas: ovogonia y foliculogénesis, crecimiento primario del ovocito, inclusiones lipídicas y gránulos corticales, vitelogénesis y maduración. La presencia de grandes filamentos que aparecen al final de la etapa de crecimiento primario, inducen adaptaciones foliculares. Durante el crecimiento 
primario, en el citoplasma se encuentran abundantes ribosomas, retículo endoplásmico rugoso y agrupamientos de mitocondrias. Al final de esta etapa, inicia el desarrollo de la capa Z1 del corion, comenzando a ser evidentes las microvellosidades del ovocito. Durante la etapa de inclusiones lipídicas y gránulos corticales, vesículas PAS positivas, algunas de ellas con material nucleoide, se ubican en la periferia del ovocito, mientras que las que contienen material graso toman una posición más central en la célula. Durante la vitelogénesis se presenta una acumulación de vitelo protéico en un sentido centrípeto; durante esta etapa, el corion está completamente formado. En la maduración, la vesicular germinal migra hacia el polo animal, se reinicia la meiosis y se rompe la envoltura nuclear. El ovocito incrementa su tamaño y en el citoplasma se pueden observar algunas gotas de grasa y el vitelo se presenta como una gran masa acuosa. En el exterior, los filamentos rodean completamente al ovocito.

Key words: Chirostoma, ovario, ultraestructura, oocitos, teleosteos.

\section{REFERENCES}

Abascal, F.J. \& A. Medina. 2005. Ultrastructure of oogenesis in bluefin tuna Thunnus thynnus. J. Morphol. 264: $148-160$.

Barbour, C.D. 1973a. The systematics and evolution of the genus Chirostoma Swainson (Piscis: Atherinidae) Tulane St. Zool. Bot. 18: 97-141.

Barbour, C.D. 1973b. A biogeographical history of Chirostoma (Piscis: Atherinidae). A species flock from Mexican plateau. Copeia 3: 533:566.

Barriga-Sosa, I.D.L.A., A.L. Aguirre-Ibañez \& J.L. Arredondo-Figueroa. 2002. Morphological and genetic variation in seven species of the endangered Chirostoma humboldtianum species group (Atheriniformes: Atherinopsidae). Int. J. Trop. Biol. Cons. 51: 199-216.

Begovac, P.C.\& R. Wallace. 1989. Major vitelline envelope proteins in pipefish oocytes originate within the follicle and are associated with Z3 layer. J. Exp. Zoo. 251: $56-73$

Blazer, V. S. 2002. Histopathological assessment of gonadal tissue in wild fishes. Fish Physiol. Biochem. 26: 85-101.

Cardenas, R. \& H. Barrera. 1998. Histología y ultraestructura del testículo del charal Chirostoma jordani (Osteichtyes: Ahterinidae). Int. J. Trop.Biol. Cons. 46: 943-949.
Cerda, J., K. Selman, S.M. Hsiao. \& R. Wallace. 1997. Evidence for the differential regulation of ovarian follicle responsiveness to human chorionic gonadotropin in vitro in a serranid teleost, Centropristis striata. Aquaculture 159: 143-157.

Cruz-Landim, C.\& M.A. Cruz-Höfling. 2001. Ultrastructure of ovarian follicular epithelium of the Amazonian fish Pseudotylosurus microps (Teleostei: Belonidae): morphological and histochemical characterization of intercellular deposits. Rev. Bras. Biol. 61: 133-140.

de Vlaming, V. 1983. Oocyte developmental patterns and hormonal involvements among teleosts. p 176-199. In J.C. Ranking, T.J. Pitcher \& R.T.Duggan (eds.). Control processes in fish physiology. Croomhelm, London, England.

Dyer, B.S. \& B. Chernoff. 1996. Phylogenetic relationships among atheriniform fishes (Teleostei: Atherinomorpha). Zool. J. Linn. Soc. 117: 1-69.

Fausto, A. M, S. Picchietti, A.R. Taddei, C. Zani, G. Scapigliati, M. Mazzini \& L. Abelli. 2004. Formation of the egg envelope of a teleost, Dicentrarchus labrax (L.): immunochemical and cytochemical detection of multiple components. Anat. Embryol. 208: 3-53.

Grier, H. 2000. Ovarian germinal epithelium and folliculogenesis in the common snook, Centropomus undecimalis (Teleostei: Centropomidae). J. Morphol. 243: 265-281.

Higashino, T., T. Miura, C. Miura \& K. Yamauchi. 2002. Histological studies on early oogenesis in barfin flounder (Verasper moseri) Zool. Sci. 19: 557-563.

Mourente, G., G. Megina \& E. Diaz-Salvago. 2002. Lipids in female northern bluefin tuna (Thunnus thynnus L.) during sexual maturation. Fish Physiol. Biochem. 24: 351-363.

Nagahama, Y. 1983. The functional morphology of teleost gonads. p 223-276. In W.S. Hoar, D.J. Randall \& E.M. Donaldson (eds.). Fish physiology, IX A. Reproduction, endocrine tissues and hormones. Academic Press, NewYork, U.S.A.

Nakamura, M. \& Y Nagahama. 1993. Ultrastructural study on the differentiation and development of steroidproducing cells during ovarian differentiation in amago salmon, Oncorhynchus rhodurus. Aquaculture 112: $237-251$.

Nagahama, Y. 1997. 17 $\alpha$, 20ß-dihydroxy-4-pregnen-3one, a maturation-inducing hormone in fish oocytes: Mechanism of synthesis and action. Steroids 62: 190-197. 
Patiño, R. \& C.V. Sullivan. 2002. Ovarian follicle growth, maturation, and ovulation in teleost fish. Fish Physiol. Biochem. 26: 57-70.

Patiño, R., P. Thomas \& G.Yoshizaki. 2003. Ovarian follicle maturation and ovulation: an integrated perspective. Fish Physiol. Biochem. 28: 30-308.

Selman, K. \& R.A. Wallace. 1983. Oogenesis in Fundulus heteroclitus. III. Vitellogenesis. J. Exp. Zool. 226: 441-457.

Selman, K., and Wallace, R. A. 1986. Gametogenesis in Fundulus heteroclitus. Am. Zool. 26: 173-192.

Selman, K., R.A. Wallace \& V. Barr. 1986. Oogenesis in Fundulus heteroclitus. IV. Yolk vesicle formation. J. Exp. Zool. 239: 277-288.
Selman, K., R.A. Wallace \& V. Barr. 1988. Oogenesis in Fundulus heteroclitus. V. The relationship of yolk vesicles and cortical alveoli. J. Exp. Zool. 246: 42-56.

Selman, K., R.A. Wallace, A. Sarka \& X. Qi. 1993. Stages of oocyte development in the zebrafish, Brachydanio rerio. J. Morphol. 218: 203-224.

Smythe, E. 2003. Clathrin-coated vesicle formation: a paradigm for coated-vesicle formation. Biochem. Soc. Trans. 31: 736-739.

Tyler, R.G. \& J.P. Sumpter. 1996. Oocyte growth and development in teleost. Rev. Fish Biol. Fish. 6: 287-318.

Wallace, R.A. \& K. Selman. 1990. Ultrastructural aspects of oogenesis and oocyte growth in fish and amphibians. J. Electron. Micros. Tech. 16: 175-201. 
